\title{
TIPOS DE POVOAMENTO RURAL NUM TRECHO DA MÉDIA DEPRESSÃO PERIFÉRICA PAULISTA.
}

\author{
MIGUEL CEZAR SANCHEZ
}

da Faculdade de Filosofia, Ciências e Letras de Rio Claro (SP).

O presente estudo foi efetuado analisando-se o povoamento rural nos municípios paulistas de São Pedro e Charqueada. Ambos estão quase que totalmente dentro da unidade fisiográfica ou morfológica do Estado de São Paulo, conhecida por Depressão Periférica Paulista, ou Depressão Paleozóica. Esta é constituida predominantemente por terrenos sedimentares de idade paleozóica. Morfologicamente, apresenta colinas de topos tabulares ou arredondados. Suas altitudes variam entre 550 a $650 \mathrm{~m}$ representando uma área de um modo geral, rebaixada entre o Planalto Atlântico situado a leste e o Planalto Arenito-Basáltico ou Ocidental que está a oeste.

Os municípios de São Pedro e Charqueada estão situados na porção Média da Depressão Periférica Paulista sendo que o primeiro apresenta pequena porção de seu território já sobre o Planalto Arenito-Basáltico. Os rebordos deste constituem a localmente conhecida "serra" de São Pedro. Esta apresenta altitudes até $950 \mathrm{~m}$, contrapondo-se portanto, com as altitudes médias da Depressão Periférica que oscilam, na área estudada entre 500 e $600 \mathrm{~m}$.

Para o desenvolvimento do presente estudo, utilizamos fotografias aéreas na escala de 1:25.000 as quais foram muito úteis na organização dos mapas da malha fundiária, dos sitemas agrícolas e das casas rurais, todos indispensáveis num estudo de povoamento rural.

$\mathrm{Da}$ análise detalhada das células de povoamento rural, com as chamou Meynier (1958), resultou o reconhecimento de vários tipos de povoamento rural. Suas características permitiram uma classificação abrangendo tipos que vão desde os mais dispersos até as aglomerações onde já se verifica um misto de feições e funções rurais e urbanas. 
Tanto dentro de cada categoria, como de uma para outra, há semelhanças e contrastes na gênese, evolução e distribuição espacial das células de povoamento rural.

Observamos uma nítida relação entre o tipo de povoamento rural e as formas de utilização da terra. Sendo assim, as modificações verificadas na maneira de se utilizar a terra, principalmente no que se refere aos tipos de produtos cuultivados, levou a transformações na malha fundiária as quais repercutiram no tipo de povoamento rural.

\section{A. - POVOAMENTO RURAL DISPERSO.}

Ao mapearmos a malha fundiária, os sitemas agrícolas e as casas rurais nos dois municípios, verificamos de imediato a predominância de unidades de povoamento, ou "habitat rural" dispersas. Porem, conforme já afirmamos, é grande a diversidade, mesmo dentro desta categoria, no que se refere ao arranjo espacial, à gênese e evolução dos mesmos.

A grande maioria dessas unidades de povoamento rural é formada por sítios com duas a quatro casas e que raramente ultrapassam 12 hectares de área. Nelas residem o proprietário com sua família, havendo mais duas ou três casas ocupadas por filhos casados, ou mais raramente, por empregados ou parceiros. Este tipo de povoamento rural foi encontrado nos dois municípios, porem, com maior frequência em Charqueada, coincidindo com a área que atualmente é ocupada pela cultura da cana-de-açucar. Em ambos os municípios a quase totalidade dessas unidades de povoamento constitui o que aparece na bibliografia sobre o assunto, como os bairros rurais. E necessário destacar que dos bairros rurais que estudamos nos dois municípios, embora sejam conscientes e perfeitamente delimitados pelos seus moradores, há uma diversidade muito grande quanto às dimensões, funções $\mathrm{e}$ arranjo espacial.

Depois de analisarmos todas essas células de povoamento rural que o próprio lavrador chama de bairro, concluimos pela validez do termo, pois se enquadra perfeitamente dentro de tudo quanto se tem escrito sobre esse tipo de povoamento rural no Estado de São Paulo. Hajam vistas as considerações e o conceito de bairro-rural emitidos por Nice Lecocq Müller (1951 e 1966).

Dada as características diferentes apresentadas dentro de uma mesma categoria de povoamento rural, julgamos conveniente uma diferenciação. Assim, o habitat rural disperso, por apresentar os típicos bairros rurais com uma densidade de ocupação inegavelmente maior do que as fazendas de gado, ou das chácaras e pequenos sítios dos 
arredores de São Pedro e Charqueada, figura com dois subtipos que são respectivamente: dispersão densa e dispersão rarefeita.

\section{a). - Dispersão Densa.}

Grande parte dos bairros rurais dos dois municípios, teve origem semelhante. Assim, a maioria deles foi antigas fazendas de café que sofreram subdivisão, quer por herança, quer por venda. Alguns bairros, especialmente aqueles alem da serra de São Pedro, permanecem ainda com café nos sítios resultantes das fazendas maiores. Outros, porem, na grande maioria, por estarem sob o raio de influência das usinas de açucar e devido às sucessivas crises experimentadas pela lavoura cafeeira, abandonaram totalmente essa atividade agrícola. Apesar desse abandono quase total, durante a crise economica do café, especialmente aquela de 1929, alguns cafezais, principalmente os que estavam sobre solos de terra-roxa, conseguiram chegar até nossos dias. Estes são mais encontrados em São Pedro do que em Charqueada, onde são exceções. O que se assistiu após a crise econômica de 1929-30 foi a passagem para uma fase de grande desenvolvimento da lavoura algodoeira devido o alto preço alcançado por esse produto na época. A policultura, fundamentada principalmente nos cereais, tambem alcançou grande desenvolvimento. Passada essa fase, com a perda da importância do algodão no mercado externo, foi a cana-de-açucar que passou desde 1944 a exercer maior influência sobre a vida dos bairros. O "verde cana", desde então, passou a dominar as propriedades desses bairros. A área destinada às lavouras de subsistência é muito pequena, sendo prática comum, entre os fornecedores, o plantio de feijão entre as fileiras de cana. Depois que esta é cortada em três safras sucessivas, procede-se à aração, fazendo-se uma lavoura de cereais que antecederá o novo plantio da cana.

Nesses bairros todo o trabalho é feito pelos seus moradores que são na maioria, os próprios proprietários, fornecedores de cana para as usinas de Paraisolândia, situada no município de Charqueada e Costa Pinto, situada já no município de Piracicaba. Os filhos dos proprietários, quando moram na propriedade, são geralmente meieiros e, nocaso de existir empregados residentes, são na grande maioria, assalariados.

Alem das casas de moradia, as unidades de povoamento desses bairros possueum ainda um rancho ou paiol onde guardam instrumentos agrícolas, algumas máquinas, cereais para consumo próprio, bem como sacarias de adubo.

E comum nesses bairros, como em, todos os demais do Estado, a existência de capela, venda e escola, locais onde se efetuam os conta- 
tos sociais da população. Em alguns casos, como no bairro da Onça, em Charqueada, é comum os proprietários reservarem pequenos lotes de dimensões urbanas, ou de meio a um alqueire para construirem suas casas nas imediações da capela, venda e escola, as quais, estão à beira de estradas importantes que levam a Charqueada e a Piracicaba. Este fato é particularmente comum no caso dos proprietários já idosos. Estes, não podendo, ou não querendo trabalhar mais, preferem morar num centro que lhes ofereça maior conforto do que as moradias das propriedades rurais. Há com isso tambem maiores possibilidades de contatos sociais e deslocamentos fáceis para as cidades próximas.

Quanto ao arranjo fisionômico, essas unidades de povoamento rural se acham ordenadas de modo a atender sempre, à necessidade de abastecimento em água, ou facilidade de transportes. Porem, nunca se encontram em fundos de vales. A regra geral de localização é a meia encosta, ou sobre os interflúvios, sempre próximo às cabeceiras fluviais.

As estradas, especialmente aquela que liga Charqueada a Piracicaba, funcionam tambem como elementos orientadores para a localização das casas, facilitando as comunicações e transporte dos moradores e da produção.

A densidade de ocupação desses bairros é baixa, quando tomada em comparação aos bairros rurais de Piracicaba. Com efeito, a professora Dra. Nice Lecoca Müller nas obras já citadas, estudou bairros que, só excepcionalmente, tinham menos de cem casas. Já em Charqueada e São Pedro esses bairros possuem em média trinta e cinco casas e só o bairro da Onça ultrapassa cinquenta, possuindo sessenta e três casas. No entanto, devido a pequena extensão das propriedades, as casas desses bairros permanecem a curta distância uma das outras, quer dentro da mesma propriedade, de uma propriedade em relação à outra. Esse fato dá para a área desses bairros a característica de um povoamento disperso, porem, denso.

Alem do bairro da Onça que conta com sessenta e três casas vamos ter os bairros da Rocinha com trinta e duas, Jacutinga com trinta e oito, Ressaca com trinta, Cateto com quarenta e duas, Paiol com vinte e nove e Limoeiro com trinta e três.

Prosseguindo na análise do habitat rural disperso denso, encontramos sobre a serra de São Pedro, ainda próximo do rebordo, o bairro Boa Vista do Jacaré e o bairro de Santo Antônio. Estes são morfologica e geneticamente diferentes entre si e tambem dos anteriormente mencionados. 
Ainda nas proximidades da descida da "serra", porem alcançando já as cabeceiras dos rios consequentes, vamos encontrar no vale do Rio Grande um dos formadores do Jacaré Pepira Mirim (afluente do Tietê) uma área onde as unidades de povoamento se caracterizam por apresentarem de uma a duas casas. Aqui tambem essas células de povoamento rural coincidem com pequenas propriedades, onde o proprietário reside com a família e, mais raramente, existe outra casa para o filho mais velho casado. Essas propriedades em número de nove formam o chamado Bairro dos Ritas. Apenas uma propriedade existe aí com duzentos e setenta alqueires, sendo que as oito restantes possuem áreas inferiores a doze alqueires. Alem das moradias, cada propridade possui, via de regra, um paiol e um curral. Os proprietários com suas famílias trabalham em suas pequenas propriedades e complementam suas atividades trabalhando como parceiros, especialmente na propriedade maior do bairro ou em fazendas mais distantes. Não há entreajuda tão comum entre os moradores de bairros, apesar da grande maioria dos habitantes serem parentes entre si. A atividade agrícola predominante é a lavouura de cereais, possuindo os proprietários uma ou duas vacas de leite para o consumo próprio. Essas atividades tambem, logicamente em maior escala, são as do único grande proprietário do bairro, o qual é fornecedor de leite para a Nestlé em São Pedro.

O vale do ribeirão Grande, tambem sobre o Planalto Arenito-Básáltico, nunca foi ocupado por lavoura de café, devido a frequência das geadas. Sendo assim, permaneceu intacto durante a expansão cafeeira na área. Em 1921 só existia no local uma venda e predominava uma cobertura florestal densa. Era a grande propriedade dos Soares que, em pontos esporádicos apresentava clareiras onde familiares e agregados faziam especialmente criação de suinos e animais de custeio. Essas atividades eram feitas em comum, cercando-se apenas as pequenas áreas cultivadas com cereais. Assim, continuaram desbravando a mata até 1923 , quando se verificou a divisão da grande propriedade em porções menores, as quais, geralmente, já possuiam uma ou duas casas de barrote, cobertas de sapé. Eram cerca de vinte a vinte e cinco dessas casas. Subdivididas, umas por herança ou venda, reagrupadas outras, chegaram hoje ao número de nove propriedades com uma só de tamanho consideravel. Esta já está com seus duzentos e setenta alqueires em processo de divisão entre quatro herdeiros. Conta atualmente o bairro com dezesseis casas e uma população de aproximadamente oitenta habitantes. Não há venda, escola ou capela.

As casas na grande maioria de tijolos e cobertas com telhas, estão situadas na baixa encosta, geralmente sobre o primeiro patamar a salvo de possíveis inundações. A orientação é nitidamente dada pelo 
vale o que constitui um fato pouco comum na área dos dois municípios. Este fato só se repete no bairro Boa Vista de Jacaré (Gomes) e na área de pequenos sitiantes situada em continuação ao bairro dos Ritas, todos alem da "serra" de São Pedro, ou seja, sobre o Planalto Arenito-Basáltico.

Ainda sobre o referido Planalto, agora bem mais próximo ao rebordo, encontramos mais uma área com predominância de uma a duas casas constituindo as unidades do povoamento rural. Estas tambem tem propriedades pequenas e as casas são construidas sobre terrenos com meio alqueire, dispostos em torno de uma capela. Nestes casos os moradores possuem suas terras nas vizinhanças, deslocando-se diariamente para o trabalho. Este é efetuado essencialmente pela família e é basicamente na lavoura de cereais ou em pequenas áreas de café. São os moradores quarenta e duas pessoas, todas parentes entre si. Aí não há tambem o costume da entreajuda. Dos oito proprietários moradores do bairro, apenas dois possuem propriedades cujas áreas ultrapassam vinte alqueires. As oito casas, a igreja, a venda, uma casa de férias dos frades capuchinhos de Piracicaba, uma escola e um campo de bochas compõem o chamado bairro de Santo Antônio. As oito casas acham-se dispostas ao longo da estrada que liga São Pedro a Itirapina e, no centro do bairro, em frente da capela, cruza a estrada que de São Pedro se dirige a Brotas e a Torrinha.

A disposição das casas está orientada, então, pelas estradas, pela proximidade da capela, venda e escola, alem de estarem bem próximas às cabeceiras dos cursos d'água subsequentes, imperativo que tende a desaparecer pelo aparecimento da água canalizada, recentemente.

Este é um exemplo típico de pequeno bairro que teve origem numa capela erguida num cruzamento de estradas onde logo se instalou uma venda. Isso quando ainda predominavam na área duas grandes fazendas cafeeiras, cercadas por outras tambem de café e que mantinham grande número de pessoas entre familiares dos proprietários e colonos. Lembrada a conveniência da edificação de uma capela, onde a numerosa população pudesse cumprir seus deveres religiosos, iniciaram-se os entendimentos para a escolha de lugar adequado para a construção. Depois de muitas disputas, pois cada qual queria que fosse em sua propriedade, concordaram ser as proximidades do cruzamento das estradas o melhor lugar. Os proprietários logo concordaram na doação do terreno e eles mesmos e mais os colonos auxiliaram na edificação da capela. Os dois proprietários das fazendas em cujas terras a igreja se ergueu, foram buscar diretamente em Pádua a imagem de Santo Antônio. Isso aconteceu em 1911, quando só existiam capela e uma venda no local. 
Por herança e posteriormente por vendas sucessivas, as duas grandes propriedades com mais de quatrocentos alqueires cada uma, foram subdivididas antes mesmo da queda do café em 1929-30. Mesmo em sítios menores a lavoura cafeeira foi mantida. Depois da grande crise econômica, os cafezais já velhos e em solos piores nas proximidades da capela foram abandonados. Outros foram arrancados ainda novos, e aqueles situados em manchas de solos melhores, apenas mantidos. Com a desvalorização das terras e do café, a situação econômica dificil dos proprietários, os antigos colonos passaram a adquirir partes ou até propriedades inteiras, onde passaram a se dedicar especialmente à lavoura de cereais, manter os cafezais existentes, quando não, plantando novos pequenos talhões, mesmo sobre solos arenosos, pouco férteis. E esta situação que alcança nossos dias, sendo especialmente a partir de 1950 que se iniciou a nova fase de construções ao redor da capela e estrada. Antes disso, os proprietários eram moradores das propriedades, ou de São Pedro, ou ainda, do bairro do Palmital situado mais adiante, seguindo a estrada que demanda a Itirapina.

Em 1950, com a doação de 5 alqueires aos frades capuchinhos de Piracicaba, para a construção de sua casa de férias, o bairro se formou propriamente dizendo pois, pelo menos seis das oito moradias foram construidas. Missas todos os meses, todos os dias nas férias, festas animadas em honra ao padroeiro, proximidade da venda, escola e estradas atrairam os sitiantes que, alem das propriedades que cultivavam, adquiriram meio alqueire para construirem suas casas atendendo àqueles fatores de atração.

Ainda alem do rebordo da "serra" de São Pedro, embora bem mais afastado deste, vamos encontrar outro exemplo de bairro rural, portanto de habitat disperso denso. Trata-se do bairro Boa Vista do Jacaré, tambem conhecido por bairro dos Gomes, ou bairro dos protestantes. Situado no curso superior do rio Jacaré Pepira Mirim já na divisa dos municípios de São Pedro e Brotas, este bairro surgiu através da ocupação inicial do lugar por uma família protestante, ou presbiteriana, de sobrenome Gomes. Esta chegou ao local quando ainda dominava, em meados do século passado, a cobertura florestal original. As duas famílias iniciaias apossaram-se da área como espécie de posseiros. Tudo era em comum, inexistindo cercas para delimitar propriedades. Assim continuou por muito tempo, sendo cercadas apenas as áreas de lavouras, continuando os animais: porcos, galinhas, cabritos e vacas, em comum.

Com o aumento do número de famílias no próprio local, ou a chegada de novos protestantes de outras áreas, foi havendo demarcação das glebas de cada família. Interessante que a área de cada propriedade foi inicialmente demarcada conforme a posse do chefe de famí- 
lia. $O$ engenheiro encarregado da demarcação ganhava por alqueire demarcado após medido. Sendo assim, cada um mandava delimitar um número de alqueires que pudesse pagar. Por essa razão, e porque as famílias eram pequenas e a terra virgem produzia bem, não houve, de início, grandes propriedades. Mesmo com essa divisão, praticamente só se cercavam as áreas de lavouras; os animais continuavam soltos em comum.

O bairro praticamente só se formou quando cada dono de lote construiu sua casa, na sua respectiva propriedade. Todas as casas eram de pau-a-pique, barreadas, cobertas de sapé e piso de terra-batida. Ainda hoje, continuam na maioria, de barrote e piso de chão-batido, porem, cobertas de telhas. Mesmo as paredes de barrote já apresentavam um acabamento melhor, sendo bem lisas, evitando-se assim, os "barbeiros" que tantas vítimas fez no bairro.

A localização das casas obedece sempre o sítio à meia-encosta do vale do rio Grande (principal formador do Jacaré Pepira Mirim) e seus afluentes. Esses vales e áreas próximas permaneceram à margem da fase cafeeira pois, sempre foram muito sujeitos a geadas.

Os moradores do bairro, cujo elemento de atração foi sempre constituido pela religião, chegaram a constituir uma comunidade de cinquenta famílias. Desde logo se dedicaram à lavoura de cereais e feijão. O sistema agrícola inicialmente posto em prática, foi o de rotação de terras ou roça. Cultivavam uma mesma área por, no máximo três anos, sem adubo, abandonando-a em seguida para capoeiras ou pastagens. Porem, com a diminuição da fertilidade natural do solo, e o aumento do número de membros na família e diminuição gradativa da propriedade por subdivisões hereditárias, chegou-se, na época atual com verdadeiros minifúndios, onde a situação, por vezes, é insustentavel. De fato, há necessidade hoje, de adubação e por vezes os lotes são tão pequenos que é impossivel sustentar uma família. Encontramos proprietários com um e meio a dois hectares. Em geral os proprietários e seus dependentes trabalham tambem nas terras de proprietários maiores da redondeza. Para isso, conforme já salientamos, às vezes são forçados a se deslocarem por duas horas com carroças ou "carrinhos" para chegarem ao local de trabalho. Isso porque o bairro acha-se praticamente envolvido por uma grande propriedade, cujo proprietário, com mais de mil alqueires, não admite lavouras em suas terras, destinando-as totalmente às pastagens. E interessante destacar que nem para o consumo próprio se faz lavouras nessa grande propriedade.

Assim, a maioria dos pequenos proprietários do bairro são parceiros nas propriedades maiores da redondeza. Hoje, o sistema agrí- 
cola empregado é o de rotação de cultivos e pastagens, havendo necessariamente o emprego de adubos.

O bairro, conforme já afirmamos, teve como elemento catalisador para sua formação e desenvolvimento, a religião. Nunca teve venda; apenas a escola foi instalada depois do templo. Situado na divisa dos municípios de São Pedro e Brotas sempre manteve maiores relações com a cidade de São Pedro, para onde sempre levaram a maioria dos produtos para venda e onde faziam seus suprimentos de uma maneira geral.

O bairro conta hoje com trinta e duas casas, reunindo aproximadamente cento e vinte pessoas.

b). - Dispersão Rarefeita.

Ao analisarmos os tipos de povoamento rural nos arredores da cidade de São Pedro, Charqueada e do município de Águas de São Pedro, pudemos constatar a existência de chácaras e pequenos sítios, onde uma ou duas casas constituem as células do povoamento rural. Geralmente o proprietário, ou o zelador e mais uma família compõem o contingente populacional dessas unidades. Destinam-se elas, no mais das vezes, à produção de leite, frutas, alguns suinos e aves para as cidades, ou servem apenas como pastagens de aluguel para pernoites de animais.

Neste último caso é frequente a propriedade não possuir casa, ou outra qualquer benfeitoria. $O$ dono mora na cidade, tendo atividades bem outras que não agrícolas. Isto acontece de modo mais frequente nos arredores de São Pedro pela parte norte já na subida da "serra" onde os solos são piores e bastante erodidos, não permitindo sequer um pasto de catingueiro.

No primeiro caso o que rege a localização das casas nessas pequenas propriedades é o interflúvio onde estão as estradas e caminhos vicinais visando sempre o abastecimento em água. Quanto à densidade de ocupação, uma diferença nítida deve ser ressaltada. Ao redor de Charqueada, as unidades de povoamento, embora dispersa, são mais densas que ao redor de São Pedro. A densidade se deve, principalmente, ao pequeno tamanho dessas chácaras, com uma ou duas casas construidas sempre na frente do lote que começa geralmente nas estradas. Isso contraria o aspecto geral de povoamento, que é essencialmente disperso, tornando-o, no caso, denso.

Continuando na análise das células de povoamento rural, constatamos a existência de um tipo disperso bastante rarefeito, representado pelas fazendas de gado, nos dois municípios. 


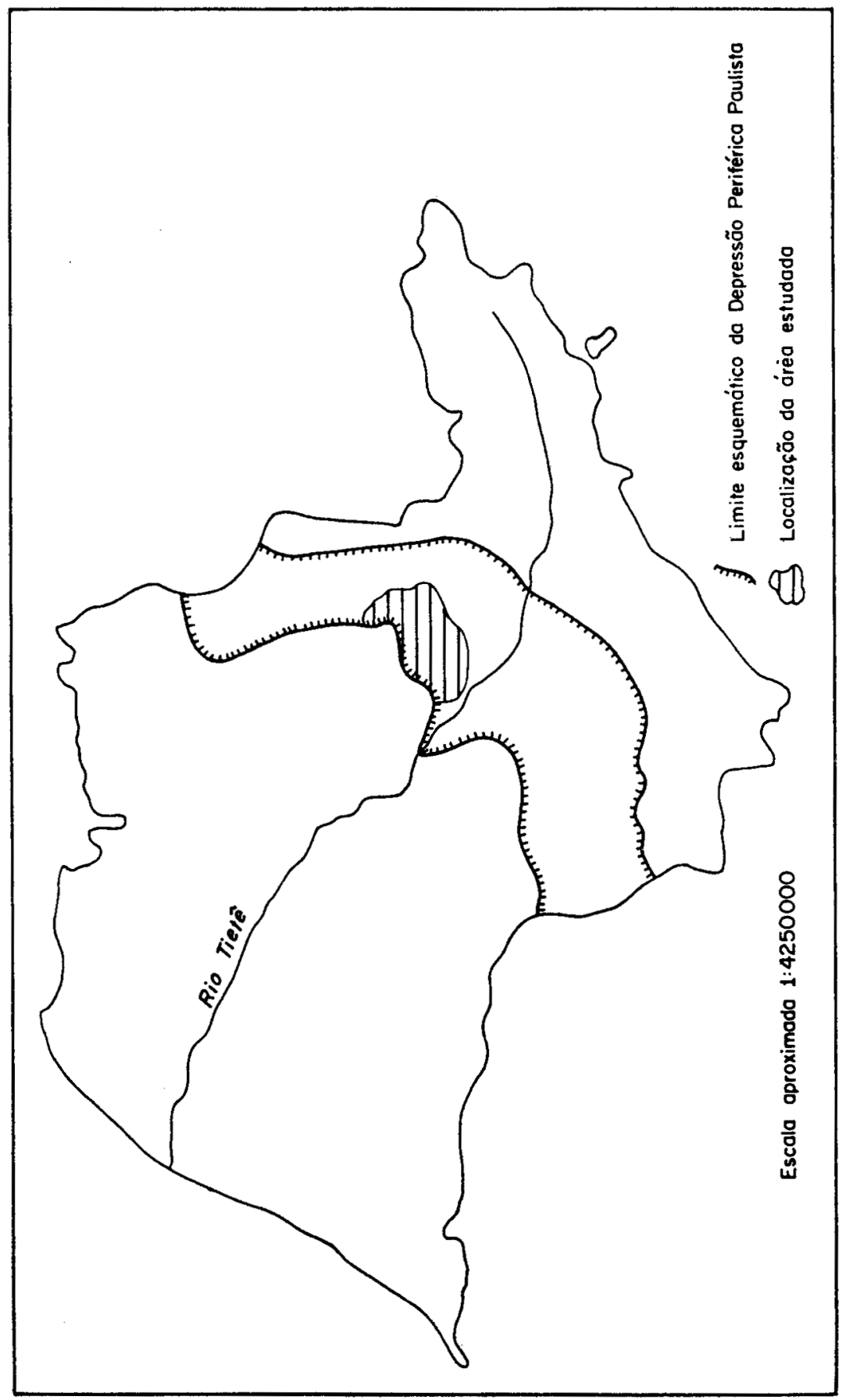




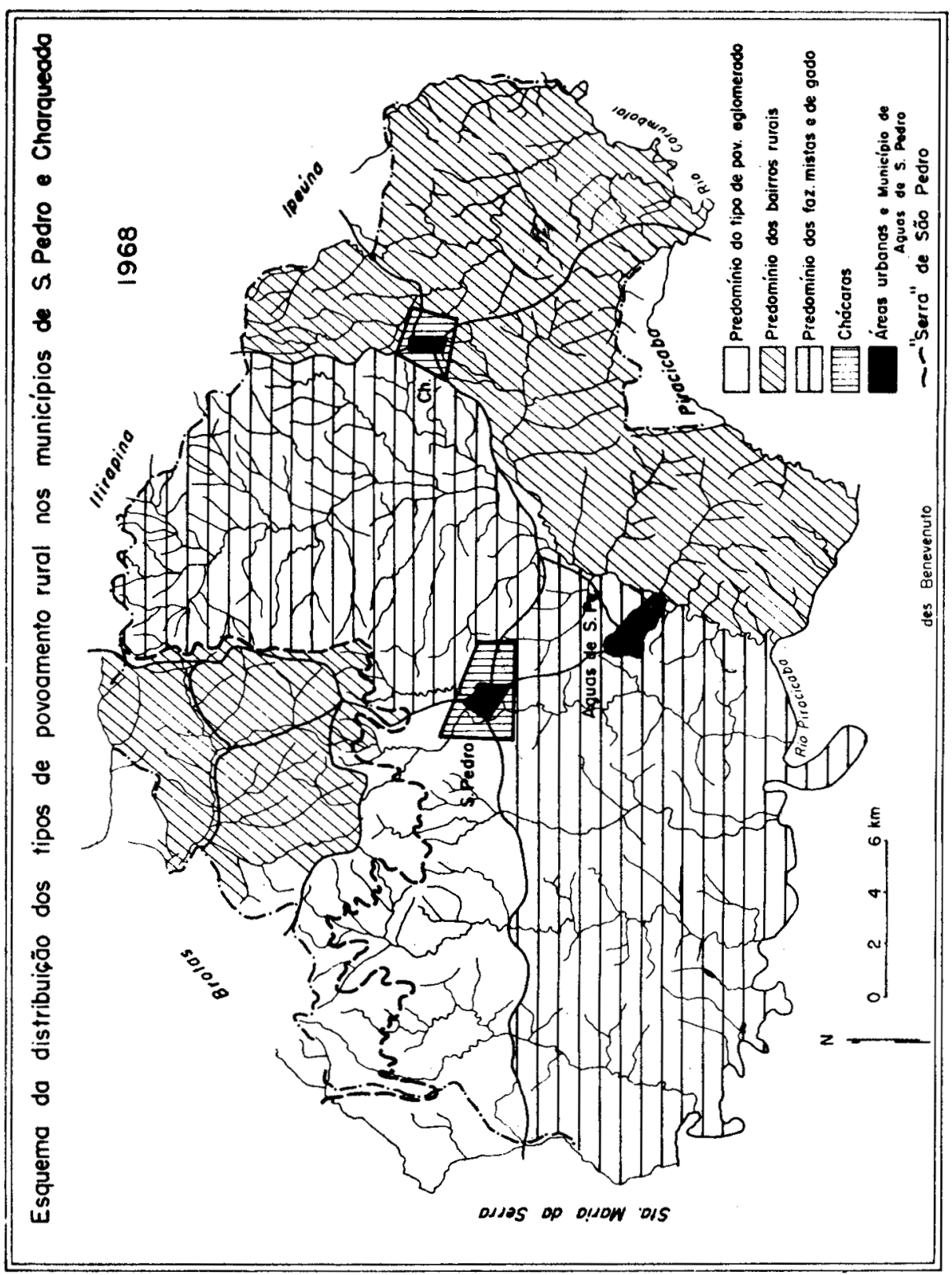


Essas unidades apresentam-se fisionomicamente semelhantes, porem geneticamente diferentes.

Assim, podemos separar as fazendas de gado que se instalaram sobre as antigas fazendas de café e que estão situadas por toda a frente da serra, desde Charqueada até São Pedro, daquelas que estão situadas entre a estrada São Pedro-Santa Maria da Serra e o rio Piracicaba. Nestas últimas, nunca tivemos lavouras de café e elas permanecem originalmente como fazendas mistas de gado e cereais, dedicando-se mais recentemente à cana-de-açucar.

Em ambos os casos, as unidades de povoamento aparecem com uma média de três a cinco casas, reservando-se uma para o proprietário que, na grande maioria dos casos, é absenteista, permanecendo portanto a casa, na maior parte do tempo, fechada. As demais são ocupadas pelo administrador que é, geralmente, o vaqueiro, dirigente da fazenda, pelo leiteiro e mais duas ou três famílias de parceiros que trabalham na lavoura de renovação de pastagens.

As casas na área de antigas fazendas de café são na maioria ainda as daquela época. Em muito casos, como nas fazendas Santa Júlia, Rosário, Campestre, aparece ainda uma parte das colônias com oito a dez casas que restaram das quarenta a cinquenta que formavam as colônias da época áurea do café.

Já na área de fazendas mistas permanecem as casas originais antigas ao lado de outras melhores recentemente construidas. Estas são especialmente destinadas à permanência curta do proprietário que é essencialmente, como dissemos, absenteista .

Quanto à distribuição espacial, verificamos a uniformidade de localização das antigas fazendas de café, hoje aproveitadas pelas fazendas de gado. Estão, todas elas ao sopé do rebordo do Planalto Ocidental sempre próxima à confluência de cursos d'água. Preferencialmente, a sede situa-se em lugar mais alto, de modo a poder dominar as colônias que se instalavam lateralmente, tambem em lugares completamente enxutos, a salvo de inundações.

Quanto às fazendas mistas ao norte do rio Piracicaba, notamos uma nítida orientação pelos interflúvios pouco pronunciados, localizando-se as casas sempre próximas às cabeceiras dos cursos d'água .

Em ambas as áreas de fazendas, quer as mistas, quer as essencialmente de gado, constatamos uma rarefação bastante grande do número de casas e de habitantes.

Em ambas as áreas de habitat essencialmente disperso, verifica-se o domínio da média e grande propriedade quase nunca inferior a du- 
zentos hectares; outras excedem de muito essa área, como aquelas situadas entre a "serra" de São Pedro e a estrada São Pedro-Santa Maria da Serra, com um mil duzentos e cinquenta, oitocentos e cinquenta e um mil hectares cada uma.

\section{B. - O "HABITAT" RURAL AGLOMERADO.}

A análise das unidades de povoamento nos propiciou ainda reconhecer povoamento rural aglomerado. Observamos fazendas com seis a oito casas sobre o Planalto ou "serra" de São Pedro, onde a economia cafeeira ainda é importante fonte de renda para seus proprietários. Nessas fazendas de café onde tambem aparecem a agricultura cerealística e o gado leiteiro, vamos encontrar alem das casas de moradia, as benfeitorias exigidas pelo café, cereais e gado. Assim, aparecem terreiros, tulhas, paióis, ranchos, currais e estábulos. A maioria dessas fazendas de café são mantidas e exploradas pelo trabalho familiar. São quatro ou cinco famílias numerosas, descendentes de antigos colonos cujos chefes são geralmente irmãos que fazem todo trabalho da fazenda sem necessidade de empregados. Cedem alguma terra a parceiros, pequenos proprietários dos bairros vizinhos, para lavouras de cereais. Noutras fazendas, onde o leite assume grande importância vamos ter assalariados que moram em casas da fazenda, pagando aluguéis e recebendo salários de $\mathrm{Cr} \$ 48,00$ (1968). Nessas fazendas, toda lavoura para renovação de pastagens é feita pelos assalariados, inexistindo a parceria. Tambem o café é cuidado pelos assalariados.

Completando as unidades de povoamento que formam o povoamento aglomerado nessas fazendas, ao lado das casas de moradia, benfeitorias para o café, gado e cereais, aparecem a escola e a capela que, por não existirem em todas fazendas, servem como locais de concentração e contatos sociais nas ocasiões festivas.

A localização dessas fazendas obedece a um sítio comum, qual seja, junto ao alto curso dos ribeirões obsequentes e nas proximidades do rebordo do planalto. Nunca as encontramos para o interior do mesmo. A densidade de ocupação dessa área alem do rebordo do planalto pode ser considerada alta, em relação às fazendas de criação, onde o número de mão-de-obra exigida é bem menor. Famílias numerosas aliadas às famílias de assalariados explicam a existência, em média, de seis a oito casas em cada célula desse tipo de povoamento rural aglomerado. Ao lado dessas atuais fazendas de café, com um tipo aglomerado de povoamento rural cujas células são compostas de seis a oito casas, necessário se torna acrescentar as atuais fazendas de gado estabelecidas sobre antigas fazendas de café. Estas, geralmente formam unidades de povoamento de oito a dez casas, relíquias de antigas co- 
lônias maiores. Poucas delas permanecem ocupadas, pois a criação extensiva de gado exige pouca mão-de-obra. Os moradores são o administrador, que geralmente é o vaqueiro, o leiteiro e mais duas ou três famílias de parceiros que fazem lavouras de cereais para renovação de pastos. São essas famílias que ocupam geralmente quatro, ou cinco, das oito, ou dez casas existentes. A casa sede da fazenda permanece fechada a maior parte do tempo, por serem os proprietários todos eles absenteístas, homens de negócio em São Pedro e Piracicaba. Porem, com a penetração canavieira que se processava nessa área, essas antigas colônias voltaram a ser ocupadas. E o caso típico da Fazenda Santa Júlia que conta com onze moradias, dez ocupadas por trabalhadores da lavoura canavieira. Alem das moradias das antigas colônias e casas sedes, ainda complementam essas unidades de povoamento a antiga tulha, o terreiro, paiois, currais, estábulos e, via de regra, a capela e escola.

Essas antigas fazendas de café localizadas no sopé da "serra" de São Pedro, cujas áreas são sempre superiores a um mil hectares, tiveram sc mpre sítios idênticos para as casas. Estão sempre próximas às confluências de ribeirões, sobre pequenos patamares que dão início à subida do rebordo do planalto. Neste particular, são idênticas àquelas fazendas de gado que, tambem estão situadas no sopé do rebordo, porem mais a leste. Estas últimas conservaram muito pouco das casas da antiga colônia, alem do fato de serem sempre menores em área e, consequentemente, em número de casas nas colônias. Estas, pelos poucos recursos do fazendeiro, eram de pau-a-pique e cobertas de sapé que, não resistindo ao tempo, não chegaram até nós.

Prosseguindo na análise das unidades de povoamento rural aglomerado, encontramos os "povoados rurais". Estão eles em meio a área atualmente ocupada pela lavoura canavieira, mantidos por esse tipo de agricultura e sua industrialização.

Atualmente o aglomerado de Recreio e de Santa Luzia, situados no município de Charqueada, funcionam como locais de residência para pequenos fornecedores de cana, seus assalariados, em menor escala para os trabalhadores da usina de Paraisolândia e donos de caminhões que transportam cana para a usina.

Originalmente, ambos os povoados surgiram da subdivisão de antigas fazendas de café.

Recreio data da segunda metade do século passado, tendo sido originado ao redor de uma capela e escola mandadas construir pelo fazendeiro que era então, o proprietário da fazenda de café que dominava a área. Esta fazenda foi subdividida por dez herdeiros da fa- 
mília Buscariol que passaram, então, a construir suas casas nas proximidades da capela e escola, deslocando-se diariamente para suas propriedades. Esses herdeiros, foram subdividindo suas propriedades e o fizeram, especialmente durante a crise cafeeira de 1929. Muitos dos antigos colonos adquiriram pequenos sítios e construiram suas casas no aglomerado perto da capela e da escola. Inicialmente, todas essas construcõos, inclusive a capela e a escola eram de pau-a-pique, barreadas e cobertas de sapé. Hoje, todas as construções são de tijolos e cobertas com telhas. As casas são dispostas em ruas e existem vendas, máquinas de beneficiar arroz e açougues. Isso compõe as funções mistas, rural e urbana do aglomerado.

O aglomerado não foge à característica geral da localização das casas nessa área. Estão tambem perto da água, distribuidas pelas duas encostas do vale de um ribeirão, afluente do rio Corumbataí. Dispõem-se, as casas, na meia encosta das duas vertentes do vale.

Conta o aglomerado de Recreio com sessenta e três casas, quatro vendas, dois bares, açougue, telefone público, agência postal, máquina de beneficiar, ferreiro, um grupo escolar, Estação da Estrada de Ferro Sorocabana, capela e com uma população de aproximadamente quinhentas pessoas. E incontestavel a predominância da função residencial de trabalhadores dependentes da lavoura açucareira. A instalação da lavoura de cana-de-açucar, especialmente a partir de 1944, é responsavel, não só pela não decadência do aglomerado, como pela manutenção e aumento da população de toda área.

O aglomerado de Santa Luzia (Tabela) que conta atualmente com trinta e nove casas e uma população de aproximadamente duzentos e cinquenta habitantes possui idênticas funções que Recreio, embora guardadas as devidas proporções dimensionais.

Quanto a origem, embora tambem de antiga fazenda de café dividida entre nove herdeiros, em 1933, Santa Luzia resultou de uma divisão cujos lotes tinham dimensões urbanas, em plena zona rural. Um dos nove herdeiros, tão logo recebeu seu quinhão, subdividiu-o em lotes de quinze metros de frente por quarenta metros de fundo, situados em ambos os lados da estrada que liga Piracicaba a Charqueada que desde então passou a servir como rua. A estrada passa por um espigão e Santa Luzia situa-se bem próximo à cabeceira d'água. Como os trabalhadores de poucos recursos pretendiam adquirir lotes e moradias, o proprietário do loteamento passou a construir essas casas e vende-las, bastante facilitado. Antes disso, em 1926, havia apenas duas casas no local, uma das quais era venda.

Foi doado um terreno para construção de uma capela a qual não chegou a ser construída por julgarem as autoridades religiosas ser o 
lote quinze por quarenta metros muito pequeno. Nesse terreno foi erguida a escola que serve o aglomerado.

Os compradores dos lotes e casas eram parceiros ou trabalhadores da lavoura canavieira. Não possuiam terras e nem eram parentes entre si. Porem, o compadrio é frequente. Como a maioria não possui terras e trabalha como assalariado, não existe aí, o sistema de entreajuda. Apenas seis das trinta e nove famílias de Santa Luzia possuem sítios nos arredores. Dez chefes de famílias trabalham na usina São Francisco do Quilombo e os demais como assalariados, ou possuem caminhões, para o transporte da cana dos sitiantes. Estes são todos fornecedores da referida usina.

O aglomerado possui, alem das trinta e nove casas, essencialmente de moradias, uma máquina de beneficiar arroz, uma oficina mecânica, uma fábrica de açucar batido, um posto de telefone público, uma escola e duas vendas.

Tanto Santa Luzia como Recreio funcionam como locais de residência dos pequenos proprietários que possuem terras nos arredores. Porem, essa função é principalmente para os assalariados que trabalham na lavoura canavieira, quer para os fornecedores, quer para a usina de Paraisolândia (na lavoura ou na indústria).

Em Santa Luzia, mais do que em Recreio, moram os donos de caminhões que trabalham para os pequenos fornecedores da usina. Isto justifica a presença de uma oficina mecânica no aglomerado.

Ainda como unidade de povoamento aglomerado identificamos a usina São Francisco do Quilombo, do distrito de Paraisolândia no município de Charqueada.

Conta atualmente o aglomerado, com grande número de casas e de habitantes, alem das edificações específicas de indústria açucareira. E uma verdadeira cidade equivalente à própria sede do município de Charqueada. Residem na sede, do distrito de Paraisolândia, perto de dois mil habitantes distribuidos em, aproximadamente, duzentas casas (1968).

Alem da população que vive essencialmente empregada em trabaIhos agrícolas ou industriais na própria usina, e que constitui a grande maioria, existe um grande número de pessoas trabalhando diretamente em atividades comerciais e demais serviços tipicamente urbanos.

O aglomerado da usina possui quatro bares, dois armazéns, uma quitanda, duas máquinas de beneficiar arroz, uma sapataria, uma farmácia, um grupo escolar, uma igreja, uma carpintaria, uma alfaiataria 
alem da cooperativa que serve os sócios e trabalhadores da usina. Tal aglomerado surgiu, totalmente, dentro da primeira fazenda adquirida para a implantação da usina açucareira. Esta fazenda era cafeicultora e possuia sua sede no local em que foi levantada a usina e, praticamente, não utilizou nada da antiga sede, a não ser as colônias e a água, já canalizada. No antigo terreiro, hoje assenta-se uma quadra de esportes da comunidade local.

Com o sucesso dos primeiros anos de produção, (início 1944), a usina vem gradativamente aumentando sua capacidade de produção, bem como a área de suas propriedades. Verifica-se, ao contrário de outras áreas, a conservação das casas nas propriedades adquiridas pela usina.

Todas as propriedades compradas nos arredores ou não da usina, permanecem com o mesmo número de casas, ou são construidas outras para abrigarem o grande número de trabalhadores da lavoura canavieira. As grandes propriedades adquiridas pela usina, geralmente, tem coincidido com as antigas fazendas de café e as antigas colônias permanecem servindo de residências aos trabalhadores da cana. Exemplos foram as fazendas Covitinga e Itaiba em Charqueada.

Quanto ao local originalmente escolhido para a localização da usina coincidiu com as vantagens de sítio apresentadas pela antiga fazenda de café: proximidade da água e da estrada de ferro. Com efeito, na confluência de quatro ribeirões que engrossam as águas do ribeirão Paraiso, afluente do Corumbataí, situa-se a sede da usina. As instalações industriais, por consumirem grande quantidade de água, se localizam na parte baixa, enquanto que as moradias se distribuem pelas encostas dos vales, desde os primeiros patamares enxutos até os espigões. Quanto ao material de construção das casas, notamos a predominância, em toda a área estudada, de construções de alvenaria. Casas de madeira ainda existem em grande quantidade, existindo ainda, em pequeno número, as de barrote com piso de chão batido. Todas elas guardam uma característica comum: são parcamente mobiliadas.

Uma vez feita essa análise, onde procuramos sempre destacar: as unidades de povoamento rural, a evolução genética das mesmas, o arranjo e distribuição das células do povoamento em relação ao meio natural, os fatos humanos e o grau de ocupação agrária, pudemos chegar às seguintes categorias de povoamento rural as quais figuram no mapa: "Os tipos de povoamento rural nos municípios de São Pedro e Charqueada".

1. - Povoamento rural disperso, denso e ordenado pelos interflúvios onde se situam as estradas e caminhos vicinais. Abrange toda 
a área compreendida entre o rio Corumbataí (afluente do Piracicaba) a oeste, tendo ao norte, as estradas de rodagem Charqueada a Ipeúna e parte daquela São Pedro-Charqueada, como limite. Abrange toda área sul e oriental do município de Charqueada e sudeste de São Pedro. Dentro dela vamos encontrar tipos de povoamento aglomerados secundários, constituidos pelos povoados de Santa Luzia, Recreio, Usina de Paraisolândia, e suas fazendas de cana que, estabelecidas sobre antigas fazendas de café, guardam ainda as características nucleadas de povoamento nas antigas colônias. Toda essa área possui uma forma de povoamento rural secundária, sendo atualmente, ocupada pela lavoura canavieira. Predominam os bairros com os sítios dos fornecedores de cana, com área nunca superior a cento e vinte hectares cada um. Nesta categoria se encontram ainda os bairros rurais situados sobre o planalto, resultantes uns da subdivisão de antigas fazendas de café, outros do povoamento original em fundo de vales e outro ainda, sobre uma encruzilhada de estradas.

2. - Povoamento rural disperso, rarefeito e ordenado, representado pelas fazendas de gado, tanto as estabelecidas sobre antigas fazendas de café como as que sempre foram mistas, de gado, cereais e algodão. Estão por toda fralda ou sopé do rebordo do Planalto Ocidental, desde o norte de Charqueada, até a frente dá escarpa do norte da cidade de São Pedro. Predominam aqui fazendas de tamanho médio, de trezentos e cinquenta hectares.

3. - Povoamento rural disperso, mais denso (intermediário entre os dois primeiros tipos), ordenado pelas estradas sobre interflúvios, representado pelos pequenos sítios e chácaras nas proximidades de São Pedro e Charqueada. Aqui as propriedades são de áreas variadas, entre dois e cinquenta hectares.

4. - Povoamento rural aglomerado e ordenado formado pelas atuais e antigas fazendas de café; aquelas sobre o reverso da "serra" de São Pedro e estas no sopé da escarpa tendo como limite a frente escarpada e a estrada de rodagem São Pedro-Santa Maria da Serra.

\section{BIBLIOGRAFIA.}

Araujo Filho (J. R. de). - O café, riqueza paulista, in: "Boletim Paulista de Geografia", 1956, número 23, pág. 106 a 113. São Paulo.

Caiuby (Júnio) . - Resenha histórica do município de São Pedro do Piracicaba. 1908. Escolas Profissionais Salesianas. São Paulo. 
Canabrava (A. P.) e Mendes (M. T.). - A regiäo de Piracicaba, ensaio de estudo regional, in "Revista do Arquivo Municipal", 1938, ano IV, vol. XIV, pág. 275 a 318 . São Paulo.

Canabrava (A. P.). - O desenvolvimento da cultura do algodão na província de São Paulo - (1861-1875). 1961. Indústria Gráfica Siqueira. São Paulo.

George (Pierre). - La campagne: Le fait rural a travers le monde. 1963. P. U. F. Paris.

- Précis de géographie rurale. 1963. P. U. F. Paris.

- Responsabilité du géographe devant le problème agricole, in: "La géographie Active" 1964 - pág. 171 a 191، P. U. F. Paris.

Meynier (A.). - Les paysagens agraires. 1958. A. Colin. Paris.

Milliet (S.). - Roteiro do café e outros ensaios. 1946. Bipa Editora. São Paulo.

Mombeig (Pierre). - As estruturas agrárias da faixa pioneira paulista. In: "Novos Estudos de Geografia Humana Brasileira", 1957, pág. 105 a 124. Difusão Européia do Livro. São Paulo.

Müller (Nice L.). - Paisagens rurais do município de Campinas, in: "Anais da A. G. B.". 1947. Vol. II, pág. 54 a 66. São Paulo.

- Sítios e sitiantes no estado de São Paulo, in: "Geografia", 1951, número 7. Faculdade de Filosofia, Ciências e Letras da Universidade de São Paulo. São Paulo.

- Bairros rurais do municipio de Piracicaba, in: "Boletim Paulista de Geografia", 1966, número 43, pág. 83 a 130. São Paulo.

Papys (Louis). - Os sistemas de cultura e suas modalidades, in: "Boletim Paulista de Geografia", 1950, número 6, pág. 23 a 31. São Paulo.

Petrone (Maria Thereza Schorer). - A lavoura canavieira em São Paulo Expansão e declínio (1765-1881). 1964. Tese de Doutoramento apresentada à Cadeira de História da Civilização Brasileira da Faculdade de Filosofia, Ciências e Letras da Universidade de São Paulo. São Paulo.

Prado Junior (Caio). - Distribuição da propriedade rural fundiária do Estado de São Paulo. In: Revista "Geografia" 1935, n $1-$ A. G. B. São Paulo. 